\title{
PENGARUH PUPUK KOMPOS LIMBAH SOLID SAWIT DAN GANDASIL D TERHADAP PERTUMBUHAN DAN HASIL TANAMAN KACANG PANJANG (Vigna sinensis L.) VARIETAS PARADE TAVI
}

\author{
Jamaluddin ${ }^{1}$ \\ ${ }^{1}$ Agroteknologi, Fakultas Pertanian, Universitas 17 Agustus 1945 Samarinda 75124, \\ Indonesia. \\ J1. Ir. H. Juanda No.80 Samarinda, 75124, Indonesia. \\ E-Mail: Jamaluddin366@gmail.com
}

\begin{abstract}
ABSTRAK
Pengaruh Pupuk Kompos Solid Limbah Sawit dan Pupuk Daun Gandasil D Terhadap Pertumbuhan dan Hasil Tanaman Kacang Panjang (Vigna sinensis L.) Varietas Parade Tavi. Tujuan penelitian untuk mengetahui pengaruh pemberian pupuk Kompos Solid Limbah Sawit dan pupuk Daun Gandasil D serta interaksinya terhadap pertumbuhan dan hasil tanaman Kacang Panjang, serta untuk mengetahui konsentrasi pupuk Kompos Solid Limbah Sawit dan pupuk Daun Gandasil D yang tepat terhadap pertumbuhan dan hasil tanaman Kacang Panjang.

Penelitian menggunakan Rancangan Acak Lengkap (RAL), dalam percobaan faktorial 3 x 3, dengan 4 ulangan. Terdiri atas 2 faktor perlakuan. Faktor I adalah pupuk Kompos Solid Limbah Sawit (S), terdiri atas 3 taraf, yaitu : $\mathrm{s}_{0}=$ tanpa pupuk kompos solid limbah sawit (kontrol), $\mathrm{s}_{1}=$ dosis pupuk kompos solid limbah sawit $40 \mathrm{~g} /$ polibag, $\mathrm{s}_{2}=$ dosis pupuk kompos solid limbah sawit $60 \mathrm{~g} /$ polibag. Faktor II adalah pupuk Daun Gandasil D (D), terdiri atas 3 taraf, yaitu : $\mathrm{d}_{0}=$ tanpa pupuk daun gandasil d (kontrol), $\mathrm{d}_{1}=$ dosis pupuk daun gandasil d $10 \mathrm{~g} / 10$ liter air, $\mathrm{d}_{2}=$ dosis pupuk daun gandasil d $30 \mathrm{~g} / 10$ liter air.

Pengaruh pemberian Pupuk Kompos Solid Limbah Sawit berbeda sangat nyata terhadap tinggi tanaman 15, 30 dan 45 HST, umur sangat berbunga, umur panen dan panjang buah per tanaman. Panjang buah per tanaman terpanjang terdapat pada perlakuan $\mathrm{s}_{1}(40 \mathrm{~g} / \mathrm{tanaman})$ yaitu $81,15 \mathrm{~cm}$.

Pengaruh pemberian Pupuk Gandasil D berbeda sangat nyata terhadap tinggi tanaman 15, 30 dan 45 HST, umur saat berbunga, umur panen dan panjang buah per tanaman. panjang buah per tanaman terpanjang terdapat pada perlakuan $\mathrm{d}_{1}(10 \mathrm{~g} / 10$ liter air) yaitu $81,15 \mathrm{~cm}$.

Pengaruh interaksi Pupuk Kompos Solid Limbah Sawit dan Pupuk Gandasil D berbeda sangat nyata terhadap tinggi tanaman umur 15, 30, 45 HST, umur panen, jumlah buah per tanaman dan panjang buah per tanaman. Berpengaruh nyata pada umur saat berbunga. Jumlah buah per tanaman terbanyak pada interaksi $\mathrm{s}_{1} \mathrm{~d}_{1}$ yaitu 8,69 ( 9 buah) dan panjang buah per tanaman terpanjang pada interaksi $\mathrm{s}_{1} \mathrm{~d}_{1}$ yaitu $83,50 \mathrm{~cm}$.
\end{abstract}

Kata kunci : Kacang Panjang, Pupuk Gandasil D, Pupuk daun, Pupuk kompos.

\begin{abstract}
The Effect of Solid Lime Palm Compost Fertilizer and Gandasil D on Growth and Yield of Long Bean (Vigna sinensis L.) Varieties of Parade Tavi. The purpose of this research is to study the effect of fertilizer Solid Waste Palm Oil Compost and Gandasil D as well as its interaction on the growth and yield of Long Beans, as well as to determine the concentration of fertilizer Solid Waste Palm Compost and Gandasil D on the growth and yield of Long Beans.

The study used a completely randomized design (CRD), in a 3 x 3 factorial experiment, with 4 replications. Consists of 2 treatment factors. The first factor is Solid Waste Palm Oil (S) compost, consisting of 3 levels, namely: $s_{0}=$ without solid compost fertilizer palm oil (control), $s_{1}=40 \mathrm{~g} /$ polybag, $s_{2}=60 \mathrm{~g} /$ polybag. The second factor is Gandasil D (D) Leaffertilizer, consisting of 3 levels, namely: $d_{0}=$ without $d$ (control), $d_{1}=$ dose of gandasil d $10 \mathrm{~g} /$ liter of water, $d_{2}=$ dose of leaffertilizer gandasil d $30 \mathrm{~g} /$ liter of water.

The effect of giving Solid Waste Palm Oil Compost was very significant on plant height 15, 30 and 45 HST, very flowe ring age, harvest age and fruit length per plant. The longest fruit length per plant was found in treatment $\mathrm{s}_{1}(40 \mathrm{~g} /$ plant $)$ which was $81.15 \mathrm{~cm}$.
\end{abstract}


The influence of the administration of Gandasil D Fertilizer was significantly different on plant height 15, 30 and 45 HST, very flowering age, harvest age and fruit length per plant. the longest fruit length per plant is found in treatment $d_{1}(10 \mathrm{~g} /$ liter of water $)$ which is $81.15 \mathrm{~cm}$.

The influence of the interaction of Solid Compost Fertilizer for Palm Waste and Gandasil D differed significantly from the height of plants aged 15, 30, 45 HST, age of harvest, number of fruit per plant and length of fruit per plant. Significant influence on age when flowering. The highest number of fruits per plant in the $S_{1} d_{1}$ interaction is 8.69 (9 pieces) and the longest fruit length per plant in $S_{1} d_{1}$ interaction is $83.50 \mathrm{~cm}$.

Key words : Compost fertilizer, Gandasil D fertilizer, Long Bean.

\section{PENDAHULUAN}

Kacang panjang (Vigna sinensis L.) merupakan salah satu komoditas sayuran yang sangat potensial untuk dikembangkan, karena mempunyai nilai ekonomis yang cukup tinggi. Dalam upaya peningkatan gizi masyarakat, kacang panjang penting sebagai sumber vitamin dan mineral.

Menurut data statistik dari BPS dari Direktor Jendral Holtikultura, produktivitas sayuran kacang panjang di Indonesia pada tahun 2011 mencapai 5,76 ton/Ha, tahun 2012 mencapai 6,02 ton/Ha, tahun 2013 mencapai 5,92 ton/Ha, tahun 2014 6,22 ton/Ha, tahun 2015 mencapai 6,26 ton/Ha. Indonesia yaitu sebesar 6,26 ton/Ha. Luas areal budidaya kacang panjang di Kalimantan Timur tahun 2015 mencapai $1357 \mathrm{Ha}$ dengan produktivitas 4,98 ton/Ha menunjukan penurunan dibandingkan tahun 2014 dengan luas area $1630 \mathrm{Ha}$ dengan produksi 5,63 ton/Ha (BPS, 2015) hai ini antara lain disebabkan oleh menurunnya tingkat kesuburan tanah dan meningkatnya serangan hama dan penyakit.

Produksi kacang panjang dapat ditingkatkan agar tidak terjadi kesenjangan bagi pendapatan yang diperoleh petani dan dapat menjadi salah satu sayuran yang mudah didapat oleh masyarakat dengan kualitas yang baik dengan upaya budidaya tanaman yang tepat, termasuk aspek pemeliharaan diantaranya yaitu pemupukan. Pada saat ini pupuk yang banyak beredar dipasaran adalah pupuk organik atau pupuk kimia.
Pemakaian pupuk kimia dalam jangka waktu yang lama dapat merusak ekosistem tanah. Penggunaan pupuk kimia juga dapat menambah keasaman tanah yang menyebabkan banyak mikroorganisme tanah yang mati. Berkurangnya mikroorganisme dalam tanah menyebabkan berkurangnya pasokan unsur hara yang dapat diserat oleh tanaman, tanaman dapat menggunakan unsur hara yang diserat untuk meningkatkan produksi dan kualitasnya.

Penelitian ini mengunakan pupuk organik yaitu pupuk kompos limbah solid sawit dan pupuk daun Gandasil D, penggunaan limbah solid sebagai pengganti pupuk kimia yang selama ini digunakan untuk menanam tanaman kacang panjang, pupuk kompos ini merupakan pupuk organik yang diperuntukkan bagi semua jenis tanaman. Kompos limbah solid ini berasal dari limbah padat pengolahan minyak sawit yang telah disimpan dalam waktu lama sehingga menjadi bentuk kompos (Sujiman, 2010 dalam Kartika, dkk, 2013).

Tujuan Penelitian adalah untuk mengetahui pengaruh pemberian pupuk kompos solid limbah sawit dan pupuk daun gandasil D terhadap pertumbuhan tanaman kacang panjang. Untuk mengetahui dosis pupuk kompos solid limbah sawit dan dosis pupuk gandasil D yang tepat terhadap hasil dan pertumbuhan kacang panjang yang baik.

\section{METODA PENELITIAN}




\subsection{Tempat dan Waktu}

Tempat penelitian di lahan Perkebunan Sawit PT. GUNTA SAMBA JAYA, di Desa Miau Baru, Kecamatan Kongbeng, Kabupaten Kutai Timur. Pada bulan MeiAgustus 2018.

\subsection{Bahan dan Alat}

Bahan penelitian yang digunakan benih tanaman kacang panjang (Vareitas Parade Tavi), tanah top soil, pupuk kompos solid limbah sawit, pupuk daun gandasil D, polybag kecil dan polybag ukuran $40 \mathrm{~cm} \times 45 \mathrm{~cm}$.

Alat yang digunakan adalah gembor, cangkul, timbangan, sabit, meteran, ember, tali rafia, pisau, kertas, lebel untuk menandai tanaman, penggaris, alat tulis, dan kamera untuk dokumentasi penelitian.

\subsection{Rancangan Percobaan}

Penelitian menggunakan

Rancangan Acak Lengkap (RAL) dalam percobaan factorial $3 \times 3$, dengan dua faktor perlakuan, diulang sebanyak 4 kali .

Kedua Faktor perlakuan tersebut adalah :

Faktor Dosis Pupuk Kompos Solid Limbah Sawit (S), terdiri atas 3 taraf, yaitu :

$\mathrm{s}_{0}$ : tanpa pupuk kompos solid limbah sawit (kontrol)

$\mathrm{s}_{1}$ : dosis pupuk kompos solid limbah sawit 10 ton/ha (40 g/tanaman)

$\mathrm{s}_{2}$ : dosis pupuk kompos solid limbah sawit 16 ton/ha (60 g/tanaman)

Faktor Dosis Pupuk Daun Gandasil

D (D), terdiri atas 3 taraf,yaitu :

$\mathrm{d}_{0}$ : tanpa pupuk daun Gandasil

D (kontrol)

$\mathrm{d}_{1}$ : dosis pupuk daun gandasil $\mathrm{D}$

10 gram /10 liter air

$\mathrm{d}_{2}$ : dosis pupuk gandasil D 30 gram/10 liter air
Setiap kombinasi perlakuan diulang sebanyak 4 kali, sehingga jumlah satuan

penelitian menjadi $4 \times 3 \times 3=36$

polibag. Penempatan suatu peneliatan menggunakan acak sederhana dengan sisitem arisan.

\subsection{Prosedur Penelitian}

Persiapan Lahan, penyemaian benih, pemeliharaan bibit, penanaman, aplikasi perlakuan, pemasangan ajir, pemeliharaan, panen.

\subsection{Pengamatan dan Pengambilan Data}

Tinggi Tanaman: tinggi tanaman diukur pada saat tanaman berumur 15 , 30, dan 45 HST. Pengukuran tinggi tanaman dilakukan $2 \mathrm{~cm}$ dari permukaan tanah yang telah diberi tanda dengan cat atau spidol pada bagian pangkal tanaman yang bersentuhan dengan tanah sampai dengan titik tumbuh cabang utama tanaman yang diteliti.

Umur Saat Berbunga (hari): dihitung sejak mulai bibit dipindah ke dalam polibag sampai dengan munculnya bunga pertama kali.

Umur Saat Panen (hari): dihitung sejak mulai bibit dipindah ke dalam polibag sampai dengan panen pertama kali.

Jumlah Buah Per Tanaman (buah): dihitung jumlah buah per tanaman setiap panen dan dijumlahkan sampai 4 kali panen.

Panjang Buah Per Tanaman $(\mathrm{cm})$ : dengan mengukur panjang buah segar pertanaman pada setiap kali panen dan diukur sampai 4 kali panen.

Berat Buah Per Tanaman (gram): dengan menimbang berat buah per tanaman pada setiap kali panen dan dijumlahkan beratnya, dari panen pertama sampai keempat. 


\subsection{Analisis Data}

Untuk menguji pengaruh perlakuan serta inteaksinya, terhadap pertumbuhan kacang panjang digunakan Uji F (Sidik Ragam) (Yitnosumarto, 1993).

Bila hasil sidik ragam terhadap perlakuan berpengaruh tidak nyata (non signifikan) yang menunjukan $\mathrm{F}$ hitung $<\mathrm{F}$ tabel 0,05 maka tidak dilakukan uji lanjutan, tetapi bila hasil sidik ragam terhadap perlakuan berpengaruh nyata (signifikan) yang menunjukan $\mathrm{F}$ hitung $>\mathrm{F}$ tabel 0.05 , maka untuk membandingkan dua ratarata perlakuan dilakukan dengan uji Beda Nyata Terkecil (BNT) dengan taraf 5\%.

Rumus Umum Uji BNT disajikan sebagai berikut :

$$
\text { BNT 5\% }=\mathrm{t} \text {-Tabel }(\alpha, \mathrm{db}) \times \sqrt{\frac{2 K T \text { Galat }}{r}}
$$

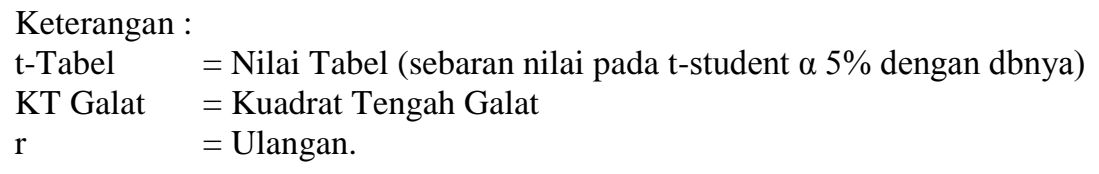

\section{HASIL PENELITIAN DAN PEMBAHASAN}

\subsection{Tinggi Tanaman Umur 15 Hari Setelah Tanam}

Hasil sidik ragam menunjukkan bahwa perlakuan Pupuk Kompos Solid Limbah Sawit (S), Pupuk Daun Gandasil $\mathrm{D}$ (D) dan interaksinya (SxD) berpengaruh sangat nyata terhadap ratarata tinggi tanaman umur 15 HST.

Hasil uji BNT 5\% perlakuan Pupuk Kompos Solid Limbah Sawit (S) terhadap tinggi tanaman umur 15 HST menunjukkan bahwa perlakuan $s_{2}(60$ g/tanaman) berbeda nyata dengan perlakuan $\mathrm{s}_{1}$ dan $\mathrm{s}_{0}$. Perlakuan $\mathrm{s}_{1}$ berbeda nyata dengan perlakuan $\mathrm{s}_{0}$. Pada umur 15 HST tinggi tanaman tertinggi pada perlakuan $s_{2}(60 \mathrm{~g} / \operatorname{tanaman})$ yaitu 29,67 $\mathrm{cm}$ dan tinggi tanaman terendah terdapat pada perlakuan tanpa Pupuk Kompos Solid Limbah Sawit $\left(\mathrm{s}_{0}\right)$ yaitu $24,92 \mathrm{~cm}$.

Hasil uji BNT 5\% perlakuan Pupuk Daun Gandasil D (D) terhadap tinggi tanaman umur 15 HST menunjukkan bahwa perlakuan $\mathrm{d}_{2}$ berbeda nyata dengan perlakuan $d_{1}$ dan $d_{0}$. Perlakuan $d_{1}$ berbeda nyata dengan perlakuan $\mathrm{d}_{0}$. Pada umur 15 HST tinggi tanaman tertinggi pada perlakuan $\mathrm{d}_{2}$ (30 gram/10 liter) yaitu $30,17 \mathrm{~cm}$ dan tinggi tanaman terendah terdapat pada perlakuan tanpa Pupuk Daun Gandasil D $\left(\mathrm{d}_{0}\right)$ yaitu $24,00 \mathrm{~cm}$.

Hasil uji BNT 5\% pada interaksi perlakuan (SxD) menunjukkan bahwa perlakuan $\mathrm{s}_{2} \mathrm{~d}_{2}$ berbeda nyata dengan perlakuan $\quad \mathrm{s}_{0} \mathrm{~d}_{1}, \quad \mathrm{~s}_{1} \mathrm{~d}_{0}, \quad \mathrm{~s}_{2} \mathrm{~d}_{0}$ dan $\quad \mathrm{s}_{0} \mathrm{~d}_{0}$. Perlakuan $\mathrm{s}_{0} \mathrm{~d}_{1}$ berbeda nyata dengan perlakuan $\mathrm{s}_{2} \mathrm{~d}_{0}$ dan $\mathrm{s}_{0} \mathrm{~d}_{0}$. Tinggi tanaman tertinggi pada interaksi $\mathrm{s}_{2} \mathrm{~d}_{2}$ yaitu 30,50 $\mathrm{cm}$ dan tinggi tanaman terendah pada interaksi $\mathrm{s}_{0} \mathrm{~d}_{0}$ yaitu $15,75 \mathrm{~cm}$.

\subsection{Tanaman Umur 30 Hari Setelah Tanam}

Hasil sidik ragam menunjukkan bahwa perlakuan Pupuk Kompos Solid Limbah Sawit (S), Pupuk Daun Gandasil $\mathrm{D}$ (D) dan interaksinya (SxD) berpengaruh sangat nyata terhadap ratarata tinggi tanaman umur $30 \mathrm{HST}$.

Hasil uji BNT 5\% perlakuan Pupuk Kompos Solid Limbah Sawit (S) terhadap tinggi tanaman umur 30 HST menunjukkan bahwa perlakuan $\mathrm{s}_{2} \quad(60$ $\mathrm{g} /$ tanaman) berbeda nyata dengan 
perlakuan $\mathrm{s}_{1}$ dan $\mathrm{s}_{0}$. Perlakuan $\mathrm{s}_{1}$ berbeda nyata dengan perlakuan $\mathrm{s}_{0}$. Pada umur 30 HST tinggi tanaman tertinggi pada perlakuan $\mathrm{s}_{2}(60 \mathrm{~g} / \mathrm{tanaman})$ yaitu 97,33 $\mathrm{cm}$ dan tinggi tanaman terendah terdapat pada perlakuan tanpa Pupuk Kompos Solid Limbah Sawit $\left(\mathrm{s}_{0}\right)$ yaitu $75,33 \mathrm{~cm}$.

Hasil uji BNT 5\% perlakuan Pupuk Daun Gandasil D (D) terhadap tinggi tanaman umur 30 HST menunjukkan bahwa perlakuan $d_{2}$ berbeda nyata dengan perlakuan $\mathrm{d}_{1}$ dan $\mathrm{d}_{0}$. Perlakuan $\mathrm{d}_{1}$ berbeda nyata dengan perlakuan $\mathrm{d}_{0}$. Pada umur 30 HST tinggi tanaman tertinggi pada perlakuan $\mathrm{d}_{2}$ (30 gram/10 liter) yaitu $98,75 \mathrm{~cm}$ dan tinggi tanaman terendah terdapat pada perlakuan tanpa Pupuk Daun Gandasil D $\left(\mathrm{d}_{0}\right)$ yaitu $73,92 \mathrm{~cm}$.

Hasil uji BNT 5\% pada interaksi perlakuan $(\mathrm{SxD})$ menunjukkan bahwa perlakuan $\mathrm{s}_{2} \mathrm{~d}_{2}$ berbeda nyata dengan perlakuan $\mathrm{s}_{1} \mathrm{~d}_{2}, \mathrm{~s}_{0} \mathrm{~d}_{2}, \mathrm{~s}_{1} \mathrm{~d}_{1}, \mathrm{~s}_{2} \mathrm{~d}_{1}, \mathrm{~s}_{0} \mathrm{~d}_{1}, \mathrm{~s}_{2} \mathrm{~d}_{0}$, $\mathrm{s}_{1} \mathrm{~d}_{0}$ dan $\mathrm{s}_{0} \mathrm{~d}_{0}$. Perlakuan $\mathrm{s}_{1} \mathrm{~d}_{2}$ berbeda nyata dengan perlakuan $\mathrm{s}_{2} \mathrm{~d}_{1}, \mathrm{~s}_{0} \mathrm{~d}_{1}, \mathrm{~s}_{2} \mathrm{~d}_{0}$, $\mathrm{s}_{1} \mathrm{~d}_{0}$ dan $\mathrm{s}_{0} \mathrm{~d}_{0}$. Perlakuan $\mathrm{s}_{2} \mathrm{~d}_{1}$ berbeda nyata dengan perlakuan $\mathrm{s}_{1} \mathrm{~d}_{0}$ dan $\mathrm{s}_{0} \mathrm{~d}_{0}$. Tinggi tanaman tertinggi pada interaksi $\mathrm{s}_{2} \mathrm{~d}_{2}$ yaitu $100,00 \mathrm{~cm}$ dan tinggi tanaman terendah pada interaksi $\mathrm{s}_{0} \mathrm{~d}_{0}$ yaitu 32,50 $\mathrm{cm}$.

\subsection{Tinggi Tanaman Umur 45 Hari Setelah Tanam}

Hasil sidik ragam menunjukkan bahwa perlakuan Pupuk Kompos Solid Limbah Sawit (S), Pupuk Daun Gandasil $\mathrm{D}$ (D) dan interaksinya (SxD) berpengaruh sangat nyata terhadap ratarata tinggi tanaman umur $45 \mathrm{HST}$.

Hasil uji BNT 5\% perlakuan Pupuk Kompos Solid Limbah Sawit (S) terhadap tinggi tanaman umur 45 HST menunjukkan bahwa perlakuan $\mathrm{s}_{1}(40$ g/tanaman) berbeda nyata dengan perlakuan $\mathrm{s}_{2}$ dan $\mathrm{s}_{0}$. Perlakuan $\mathrm{s}_{2}$ berbeda nyata dengan perlakuan $\mathrm{s}_{0}$. Pada umur 45 HST tinggi tanaman tertinggi pada perlakuan $\mathrm{s}_{1}$ (40 g/tanaman) yaitu 359,50 $\mathrm{cm}$ dan tinggi tanaman terendah terdapat pada perlakuan tanpa Pupuk Kompos Solid Limbah Sawit $\left(\mathrm{s}_{0}\right)$ yaitu $329,00 \mathrm{~cm}$.

Hasil uji BNT 5\% perlakuan Pupuk Daun Gandasil D (D) terhadap tinggi tanaman umur 45 HST menunjukkan bahwa perlakuan $\mathrm{d}_{2}$ berbeda nyata dengan perlakuan $d_{1}$ dan $d_{0}$. Perlakuan $d_{1}$ berbeda nyata dengan perlakuan $\mathrm{d}_{0}$. Pada umur 45 HST tinggi tanaman tertinggi pada perlakuan $\mathrm{d}_{2}$ (30 gram/10 liter) yaitu $366,50 \mathrm{~cm}$ dan tinggi tanaman terendah terdapat pada perlakuan tanpa Pupuk Daun Gandasil D $\left(\mathrm{d}_{0}\right)$ yaitu $314,17 \mathrm{~cm}$.

Hasil uji BNT 5\% pada interaksi perlakuan (SxD) menunjukkan bahwa perlakuan $\mathrm{s}_{2} \mathrm{~d}_{2}$ berbeda nyata dengan perlakuan $s_{1} d_{2}, s_{0} d_{1}, s_{0} d_{2}, s_{1} d_{0}, s_{2} d_{1}, s_{1} d_{1}$, $\mathrm{s}_{2} \mathrm{~d}_{0}$ dan $\mathrm{s}_{0} \mathrm{~d}_{0}$. Perlakuan $\mathrm{s}_{1} \mathrm{~d}_{2}$ berbeda nyata dengan perlakuan $\mathrm{s}_{1} \mathrm{~d}_{0}, \mathrm{~s}_{2} \mathrm{~d}_{1}, \mathrm{~s}_{1} \mathrm{~d}_{1}$, $\mathrm{s}_{2} \mathrm{~d}_{0}$ dan $\mathrm{s}_{0} \mathrm{~d}_{0}$. Perlakuan $\mathrm{s}_{1} \mathrm{~d}_{0}$ berbeda nyata dengan perlakuan $\mathrm{s}_{2} \mathrm{~d}_{1}, \mathrm{~s}_{1} \mathrm{~d}_{1}, \mathrm{~s}_{2} \mathrm{~d}_{0}$ dan $s_{0} d_{0}$. Perlakuan $s_{2} d_{1}$ berbeda nyata dengan perlakuan $\mathrm{s}_{1} \mathrm{~d}_{1}, \mathrm{~s}_{2} \mathrm{~d}_{0}$ dan $\mathrm{s}_{0} \mathrm{~d}_{0}$. Perlakuan $\mathrm{s}_{1} \mathrm{~d}_{1} \mathrm{~s}_{2} \mathrm{~d}_{1}$ berbeda nyata dengan perlakuan $\mathrm{s}_{2} \mathrm{~d}_{0}$ dan $\mathrm{s}_{0} \mathrm{~d}_{0}$. Perlakuan $\mathrm{s}_{2} \mathrm{~d}_{0}$ berbeda nyata dengan perlakuan $\mathrm{s}_{0} \mathrm{~d}_{0}$. Tinggi tanaman tertinggi pada interaksi $\mathrm{s}_{2} \mathrm{~d}_{2}$ yaitu $369,00 \mathrm{~cm}$ dan tinggi tanaman terendah pada interaksi $\mathrm{s}_{0} \mathrm{~d}_{0}$ yaitu 262,50 $\mathrm{cm}$.

\subsection{Umur Saat Berbunga (hari)}

Hasil sidik ragam menunjukkan bahwa perlakuan Pupuk Kompos Solid Limbah Sawit (S) dan Pupuk Daun Gandasil D (D) berpengaruh sangat nyata dan interaksinya $(\mathrm{SxD})$ berpengaruh nyata terhadap rata-rata umur saat berbunga.

Hasil uji BNT 5\% perlakuan Pupuk Kompos Solid Limbah Sawit (S) terhadap umur saat berbunga menunjukkan bahwa perlakuan $\mathrm{s}_{0}$ (tanpa Pupuk Kompos Solid Limbah Sawit) berbeda nyata dengan perlakuan $s_{1}$ dan $s_{2}$. Pada umur saat berbunga tercepat pada perlakuan $s_{2}(60$ 
g/tanaman) yaitu 44,00 (44 hari) dan umur saat berbunga terlambat terdapat pada perlakuan tanpa Pupuk Kompos Solid Limbah Sawit $\left(\mathrm{s}_{0}\right)$ yaitu 45,08 (45 hari).

Hasil uji BNT 5\% perlakuan Pupuk Daun Gandasil D (D) terhadap umur saat berbunga menunjukkan bahwa perlakuan $\mathrm{d}_{0}$ berbeda nyata dengan perlakuan $\mathrm{d}_{1}$ dan $\mathrm{d}_{2}$. Pada umur saat berbunga tercepat pada perlakuan $\mathrm{d}_{2}$ (30 gram/10 liter) yaitu 43,50 (44 hari) dan umur saat berbunga terlambat terdapat pada perlakuan tanpa Pupuk Daun Gandasil D $\left(\mathrm{d}_{0}\right)$ yaitu 46,00 (46 hari).

Hasil uji BNT 5\% pada interaksi perlakuan $(\mathrm{SxD})$ menunjukkan bahwa perlakuan $\mathrm{s}_{0} \mathrm{~d}_{0}$ berbeda nyata dengan perlakuan $\mathrm{s}_{2} \mathrm{~d}_{0}, \mathrm{~s}_{0} \mathrm{~d}_{2}, \mathrm{~s}_{0} \mathrm{~d}_{1}, \mathrm{~s}_{1} \mathrm{~d}_{1}, \mathrm{~s}_{2} \mathrm{~d}_{1}, \mathrm{~s}_{2} \mathrm{~d}_{2}$, dan $\mathrm{s}_{1} \mathrm{~d}_{2}$. Umur saat berbunga tercepat pada interaksi $\mathrm{s}_{1} \mathrm{~d}_{2}$ yaitu 43,00 (43 hari) dan umur saat berbunga terlambat pada interaksi $\mathrm{s}_{0} \mathrm{~d}_{0}$ yaitu 47,50 (48 hari).

\subsection{Umur Panen}

Hasil sidik ragam menunjukkan bahwa perlakuan Pupuk Kompos Solid Limbah Sawit (S), Pupuk Daun Gandasil $\mathrm{D}$ (D) dan interaksinya (SxD) berpengaruh sangat nyata terhadap ratarata umur saat panen.

Hasil uji BNT 5\% perlakuan Pupuk Kompos Solid Limbah Sawit (S) terhadap umur saat berbunga menunjukkan bahwa perlakuan $\mathrm{s}_{0}$ (tanpa Pupuk Kompos Solid Limbah Sawit) berbeda nyata dengan perlakuan $s_{1}$ dan $s_{2}$. Pada umur panen tercepat pada perlakuan $\mathrm{s}_{2}(60 \mathrm{~g} / \mathrm{tanaman})$ yaitu 53,00 (53 hari) dan umur panen terlambat terdapat pada perlakuan tanpa Pupuk Kompos Solid Limbah Sawit $\left(\mathrm{s}_{0}\right)$ yaitu 54,08 (54 hari).

Hasil uji BNT 5\% perlakuan Pupuk Daun Gandasil D (D) terhadap umur panen menunjukkan bahwa perlakuan $\mathrm{d}_{0}$ berbeda nyata dengan perlakuan $d_{1}$ dan $\mathrm{d}_{2}$. Pada umur panen tercepat pada perlakuan $\mathrm{d}_{2}$ (30 gram/10 liter) yaitu
52,50 (53 hari) dan umur panen terlambat terdapat pada perlakuan tanpa Pupuk Daun Gandasil D $\left(\mathrm{d}_{0}\right)$ yaitu 55,00 (55 hari).

Hasil uji BNT 5\% pada interaksi perlakuan $(\mathrm{SxD})$ menunjukkan bahwa perlakuan $\mathrm{s}_{0} \mathrm{~d}_{0}$ berbeda nyata dengan perlakuan $\mathrm{s}_{2} \mathrm{~d}_{0}, \mathrm{~s}_{0} \mathrm{~d}_{2}, \mathrm{~s}_{0} \mathrm{~d}_{1}, \mathrm{~s}_{1} \mathrm{~d}_{1}, \mathrm{~s}_{2} \mathrm{~d}_{1}, \mathrm{~s}_{2} \mathrm{~d}_{2}$, dan $\mathrm{s}_{1} \mathrm{~d}_{2}$. Umur panen tercepat pada interaksi $\mathrm{s}_{1} \mathrm{~d}_{2}$ yaitu 52,00 (52 hari) dan umur panen terlambat pada interaksi $\mathrm{s}_{0} \mathrm{~d}_{0}$ yaitu 56,50 (57 hari).

\subsection{Jumlah Buah per Tanaman}

Hasil sidik ragam menunjukkan bahwa perlakuan Pupuk Kompos Solid Limbah Sawit (S) dan Pupuk Daun Gandasil D (D) berpengaruh tidak nyata dan interaksinya $(\mathrm{SxD})$ berpengaruh sangat nyata terhadap rata-rata jumlah buah per tanaman.

Hasil uji BNT 5\% pada interaksi perlakuan $(\mathrm{SxD})$ menunjukkan bahwa perlakuan $\mathrm{s}_{1} \mathrm{~d}_{1}$ berbeda nyata dengan perlakuan $\mathrm{s}_{2} \mathrm{~d}_{0}, \mathrm{~s}_{0} \mathrm{~d}_{2}, \mathrm{~s}_{0} \mathrm{~d}_{1}, \mathrm{~s}_{2} \mathrm{~d}_{2}, \mathrm{~s}_{1} \mathrm{~d}_{2}, \mathrm{~s}_{2} \mathrm{~d}_{1}$, $\mathrm{s}_{1} \mathrm{~d}_{0}$ dan $\mathrm{s}_{0} \mathrm{~d}_{0}$. Perlakuan $\mathrm{s}_{2} \mathrm{~d}_{0}$ berbeda nyata dengan perlakuan $\mathrm{s}_{2} \mathrm{~d}_{1}, \mathrm{~s}_{1} \mathrm{~d}_{0}$ dan $\mathrm{s}_{0} \mathrm{~d}_{0}$. Perlakuan $\mathrm{s}_{2} \mathrm{~d}_{1}$ berbeda nyata dengan perlakuan $\mathrm{s}_{1} \mathrm{~d}_{0}$ dan $\mathrm{s}_{0} \mathrm{~d}_{0}$. Perlakuan $\mathrm{s}_{1} \mathrm{~d}_{0}$ berbeda nyata dengan perlakuan $\mathrm{s}_{0} \mathrm{~d}_{0}$. Jumlah buah per tanaman terbanyak pada interaksi $\mathrm{s}_{1} \mathrm{~d}_{1}$ yaitu 8,69 (9 buah) dan jumlah buah per tanaman yang sedikit pada interaksi $\mathrm{s}_{0} \mathrm{~d}_{0}$ yaitu 3,63 (4 buah).

\subsection{Panjang Buah per Tanaman}

Hasil sidik ragam menunjukkan bahwa perlakuan Pupuk Kompos Solid Limbah Sawit (S), Pupuk Daun Gandasil $\mathrm{D}$ (D) dan interaksinya (SxD) berpengaruh sangat nyata terhadap ratarata panjang buah per tanaman.

Hasil uji BNT 5\% perlakuan Pupuk Kompos Solid Limbah Sawit (S) terhadap panjang buah per tanaman menunjukkan bahwa perlakuan $\mathrm{s}_{1} \quad(40 \mathrm{~g} / \mathrm{tanaman})$ berbeda nyata dengan perlakuan $\mathrm{s}_{2}$ dan $\mathrm{s}_{0}$. 
Perlakuan $\mathrm{s}_{2}$ berbeda nyata dengan perlakuan $\mathrm{s}_{0}$. Pada panjang buah per tanaman terpanjang terdapat pada perlakuan $\mathrm{s}_{1}(40 \mathrm{~g} / \mathrm{tanaman})$ yaitu 81,15 $\mathrm{cm}$ dan panjang buah per tanaman terpendek terdapat pada perlakuan tanpa Pupuk Kompos Solid Limbah Sawit ( $\left.\mathrm{s}_{0}\right)$ yaitu $73,73 \mathrm{~cm}$.

Hasil uji BNT 5\% perlakuan Pupuk Daun Gandasil D (D) terhadap panjang buah per tanaman menunjukkan bahwa perlakuan $d_{1}$ berbeda nyata dengan perlakuan $\mathrm{d}_{2}$ dan $\mathrm{d}_{0}$. Perlakuan $\mathrm{d}_{2}$ berbeda nyata dengan perlakuan $\mathrm{d}_{0}$. Pada panjang buah per tanaman terpanjang terdapat pada perlakuan $\mathrm{d}_{1}$ (10 gram/10 liter) yaitu $81,15 \mathrm{~cm}$ dan panjang buah per tanaman terpendek terdapat pada perlakuan tanpa
Pupuk Daun Gandasil D $\left(\mathrm{d}_{0}\right)$ yaitu 73,90 $\mathrm{cm}$.

Hasil uji BNT 5\% pada interaksi perlakuan $(\mathrm{SxD})$ menunjukkan bahwa perlakuan $\mathrm{s}_{1} \mathrm{~d}_{1}$ berbeda nyata dengan perlakuan $\mathrm{s}_{0} \mathrm{~d}_{2}$, dan $\mathrm{s}_{0} \mathrm{~d}_{0}$. Panjang buah per tanaman terpanjang pada interaksi $\mathrm{s}_{1} \mathrm{~d}_{1}$ yaitu $83,50 \mathrm{~cm}$ dan panjang buah per tanaman terpendek pada interaksi $\mathrm{s}_{0} \mathrm{~d}_{0}$ yaitu $63,13 \mathrm{~cm}$.

\subsection{Berat Buah per Tanaman}

Hasil sidik ragam menunjukkan bahwa perlakuan Pupuk Kompos Solid Limbah Sawit (S), Pupuk Daun Gandasil D (D) dan interaksinya (SxD) berpengaruh tidak nyata terhadap ratarata berat buah per tanaman.

Tabel 1. Rekapitulasi Data Penelitian Pengaruh Pupuk Kompos Limbah Kelapa Sawit dan Pupuk Daun Gandasil D Terhadap Pertumbuhan dan Hasil Tanaman Kacang Panjang (Vigna sinensis L.) varietas Parade Tavi

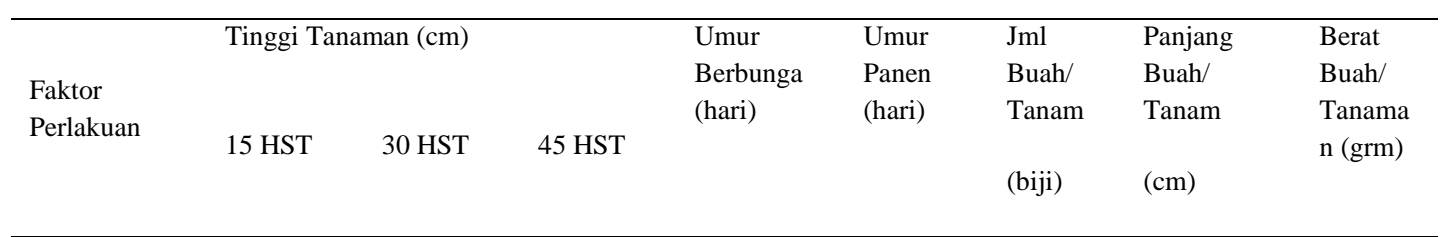

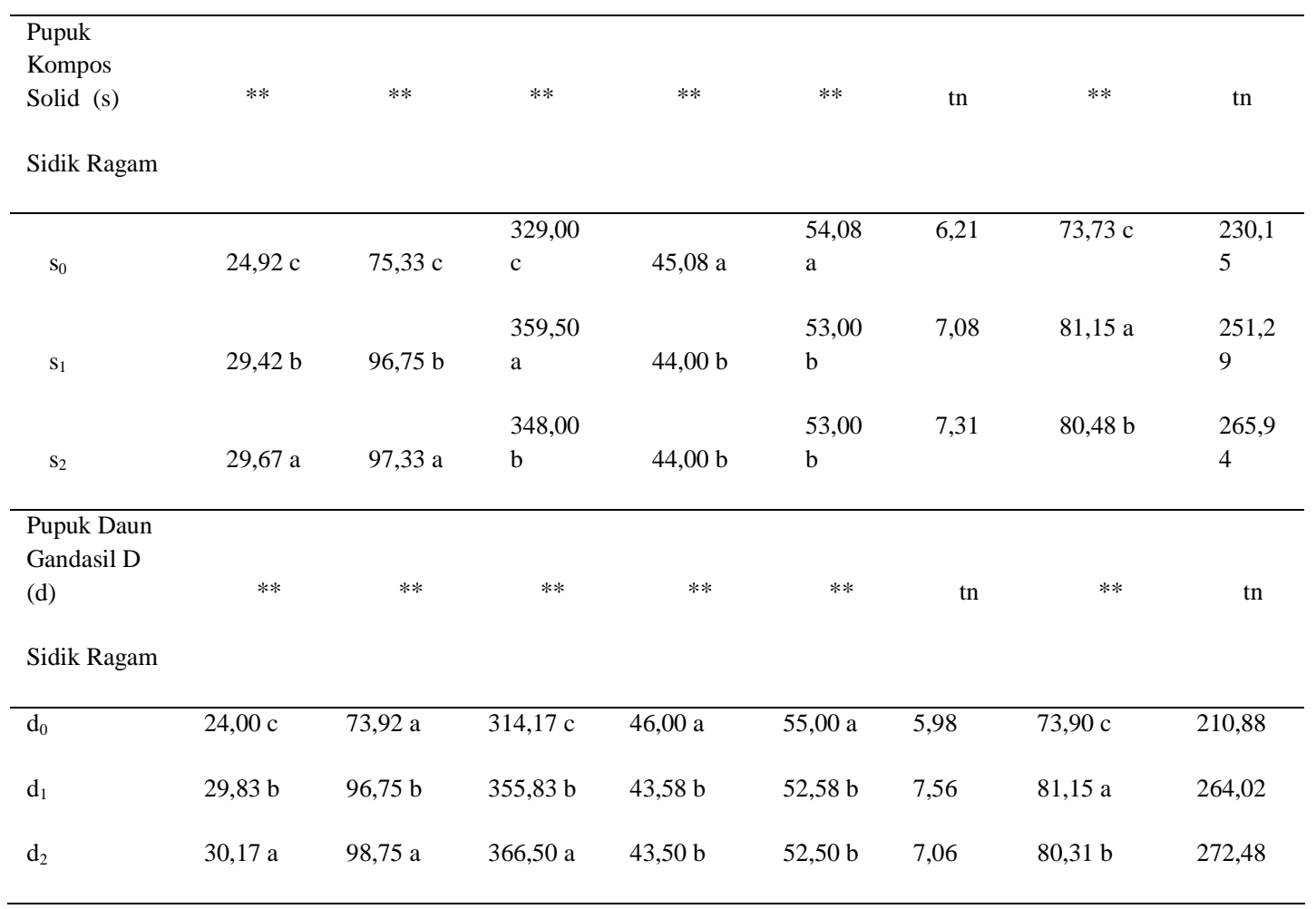




\begin{tabular}{|c|c|c|c|c|c|c|c|c|}
\hline $\begin{array}{l}\text { Interaksi } \\
(\mathrm{KxR})\end{array}$ & $* *$ & $* *$ & $* *$ & $* *$ & $* *$ & $* *$ & $* *$ & tn \\
\hline \multicolumn{9}{|c|}{ Sidik Ragam } \\
\hline $\mathrm{s}_{0} \mathrm{~d}_{0}$ & $15,75 \mathrm{c}$ & $32,50 \mathrm{~d}$ & $262,50 \mathrm{~g}$ & $47,50 \mathrm{a}$ & $56,50 \mathrm{a}$ & $3,63 \mathrm{e}$ & $63,13 \mathrm{c}$ & 139,75 \\
\hline $\mathrm{s}_{0} \mathrm{~d}_{1}$ & $29,25 \mathrm{~b}$ & $95,50 \mathrm{c}$ & $362,50 \mathrm{~b}$ & $43,75 \mathrm{~b}$ & $52,75 \mathrm{~b}$ & $7,31 \mathrm{~b}$ & $81,63 \mathrm{a}$ & 266,50 \\
\hline $\mathrm{s}_{0} \mathrm{~d}_{2}$ & 29,75 a & $98,00 \mathrm{~b}$ & $362,00 \mathrm{~b}$ & $44,00 \mathrm{~b}$ & $53,00 \mathrm{~b}$ & $7,69 \mathrm{~b}$ & $76,44 \mathrm{~b}$ & 284,19 \\
\hline $\mathrm{s}_{1} \mathrm{~d}_{0}$ & $28,25 \mathrm{~b}$ & $94,50 \mathrm{~d}$ & $360,00 \mathrm{c}$ & $45,50 \mathrm{a}$ & $54,50 \mathrm{a}$ & $5,88 \mathrm{~d}$ & $77,75 \mathrm{a}$ & 202,19 \\
\hline $\mathrm{s}_{1} \mathrm{~d}_{1}$ & $29,75 \mathrm{a}$ & $97,50 \mathrm{~b}$ & $350,00 \mathrm{e}$ & $43,50 \mathrm{~b}$ & $52,50 \mathrm{~b}$ & $8,69 \mathrm{a}$ & $83,50 \mathrm{a}$ & 284,94 \\
\hline $\mathrm{s}_{1} \mathrm{~d}_{2}$ & $30,25 \mathrm{a}$ & $98,25 \mathrm{~b}$ & $368,50 \mathrm{~b}$ & $43,00 \mathrm{~b}$ & $52,00 \mathrm{~b}$ & $6,69 \mathrm{~b}$ & 82,19 a & 266,75 \\
\hline $\mathrm{s}_{2} \mathrm{~d}_{0}$ & $28,00 \mathrm{c}$ & $94,75 \mathrm{c}$ & $320,00 \mathrm{f}$ & $45,00 \mathrm{~b}$ & $54,00 \mathrm{~b}$ & $8,44 \mathrm{~b}$ & 80,81 a & 290,69 \\
\hline $\mathrm{s}_{2} \mathrm{~d}_{1}$ & $30,50 \mathrm{a}$ & $97,25 \mathrm{c}$ & $355,00 \mathrm{~d}$ & $43,50 \mathrm{~b}$ & $52,50 \mathrm{~b}$ & $6,69 \mathrm{c}$ & $78,31 \mathrm{a}$ & 240,63 \\
\hline $\mathrm{s}_{2} \mathrm{~d}_{2}$ & $30,50 \mathrm{a}$ & $100,00 \mathrm{a}$ & $369,00 \mathrm{a}$ & $43,50 \mathrm{~b}$ & $52,50 \mathrm{~b}$ & $6,81 \mathrm{~b}$ & $82,31 \mathrm{a}$ & 266,50 \\
\hline
\end{tabular}

Keterangan :

* : berbeda nyata

**: berbeda sangat nyata

tn : berbeda tidak nyata

HST : Hari Setelah Tanam

Pengaruh Pupuk Kompos Solid Limbah Sawit Terhadap Pertumbuhan dan Hasil Tanaman Kacang Panjang (Vigna sinensis L.) varietas Parade Tavi. Hasil sidik ragam menunjukkan bahwa perlakuan Pupuk Kompos Solid Limbah Sawit (S) berpengaruh sangat nyata terhadap tinggi tanaman 15, 30 dan 45 HST, umur saat berbunga, umur panen dan panjang buah per tanaman. Berpengaruh tidak nyata terhadap jumlah buah per tanaman dan berat buah per tanaman.

Perlakuan Pupuk Kompos Solid Limbah Sawit berpengaruh sangat nyata terhadap tinggi tanaman 15,30 dan 45 HST. Dari hasil BNT 5\% rata-rata tinggi tanaman tertinggi pada perlakuan $\mathrm{s}_{2}(60$ g/tanaman) yaitu $29,67 \mathrm{~cm}$ pada umur 15 HST, $97,33 \mathrm{~cm}$ pada umur $30 \mathrm{HST}$. Pada umur 45 HST rata-rata tinggi tanaman tertinggi pada perlakuan $\mathrm{s}_{1} \quad(40$ g/tanaman) yaitu $359,50 \mathrm{~cm}$. Hal Ini

$$
\begin{aligned}
& \mathrm{s}_{0}: \text { tanpa pupuk kompos solid atau kontrol } \\
& \mathrm{s}_{1}: \text { dosis pupuk kompos solid } 40 \mathrm{~g} / \text { tanaman } \\
& \mathrm{s}_{2}: \text { dosis pupuk kompos solid } 60 \mathrm{~g} / \text { tanaman } \\
& \mathrm{d}_{0}: \text { tanpa pupuk gandasil D atau kontrol } \\
& \mathrm{d}_{1}: \text { dosis pupuk gandasil D } 10 \mathrm{~g} / 10 \text { liter air } \\
& \mathrm{d}_{2}: \text { dosis pupuk gandasil D } 30 \mathrm{~g} / 10 \text { liter air }
\end{aligned}
$$

diduga bahan organik dari kompos solid tersebut telah membuat tanah ultisol yang banyak mengandung liat menjadi gembur sehingga akar tanaman menjadi lebih berkembang dan mampu menyerap unsur hara dari dalam tanah lebih banyak. Selain itu pemberian kompos solid juga telah menyumbangkan unsur hara $\mathrm{N}$ yang tinggi sehingga meningkatkan pertumbuhan vegetatif tanaman. Berdasarkan hasil penelitian dan analisis dari laboratorium yang sudah dilaksanakan dapat diambil kesimpulan bahwa kompos KOTAKPLUS memiliki nilai $\mathrm{pH}$ yaitu 10,1, C-Organik 21,06\%, $\mathrm{N}$ sebesar $0,94 \%, \mathrm{P}$ sebesar $2,19 \%, \mathrm{~K}$ sebesar 2,94\%, Ca sebesar 6,24\%, Mg sebesar 2,19 \%, C/N Ratio sebesar 22,40 $\%$, dan Kadar Air sebesar 132,42 \%. Kompos KOTAKPLUS dapat memperbaiki sifat kimia tanah ultisol dengan dosis perlakuan yang terbaik adalah pada perlakuan D (KOTAKPLUS 
30 ton/ha) dengan peningkatan nilai $\mathrm{pH}$ 0,70, C-Organik sebesar 2,14 \%, P sebesar 99,13 ppm, Ca sebesar 0,99 me/100 g tanah, dan Al-dd mengalami penurunan sampai tidak terukur (Haitami dan Wahyudi, 2019).

Hal ini sesuai dengan pendapat Hanafiah (2005) dan Hardjowigeno (2003) yang menyatakan bahwa dalam masa vegetatif tanaman membutuhkan unsur hara $\mathrm{N}$ untuk membentuk $\mathrm{N}$, cabang, dan ranting.

Dari hasil pengamatan pada fase generatif yaitu umur saat berbunga dan umur panen berpengaruh sangat nyata. Hasil BNT 5\% umur saat berbunga tercepat pada perlakuan $\mathrm{s}_{2}(60 \mathrm{~g} / \mathrm{tanaman})$ yaitu 44,00 (44 hari) dan umur panen tercepat pada perlakuan $\mathrm{s}_{2}(60 \mathrm{~g} / \mathrm{tanaman})$ yaitu 53,00 (53 hari). Hal ini diduga adanya penambahan kompos solid bagus untuk perkembangan mikroorganisme tanah sehingga akhirnya terjadi perbaikan sifat fisik tanah. Kataren dan Djatmiko (1981) menyatakan fosfor merupakan salah satu unsur makro utama bagi pembungaan tanaman, yang pada umumnya untuk memacu munculnya bunga dan mempengaruhi kualitas bunga.

Hasil sidik ragam panjang buah per tanaman menunjukkan berpengaruh sangat nyata. Hasil BNT 5\% panjang buah per tanaman terpanjang terdapat pada perlakuan $\mathrm{s}_{1}(40 \mathrm{~g} / \mathrm{tanaman})$ yaitu $81,15 \mathrm{~cm}$. Hal ini disebabkan karena peningkatan aktivitas fotosintesis dapat meningkatkan fotosintat yang terbentuk, kemudian transfer kebiji sebagai cadangan makanan. Sehingga makin besar cadangan makanan yang terbentuk dalam biji, semakin berat polong tanaman. Secara tidak langsung akan berpengaruh terhadap ukuran panjang polong. Peningkatan panjang berarti terjadi pula peningkatan jumlah biji yang terdapat pada polong (Okalia dkk, 2018).

Pengaruh Pupuk Daun Gandasil D

Terhadap Pertumbuhan dan Hasil
Tanaman Kacang Panjang (Vigna sinensis L.) varietas Parade Tavi. Hasil sidik ragam menunjukkan bahwa perlakuan Pupuk Gandasil D (D) berpengaruh sangat nyata terhadap tinggi tanaman 15, 30 dan 45 HST, umur saat berbunga, umur panen dan panjang buah per tanaman. Berpengaruh tidak nyata terhadap jumlah buah per tanaman dan berat buah per tanaman.

Perlakuan Pupuk Gandasil berpengaruh sangat nyata terhadap tinggi tanaman 15, 30 dan 45 HST. Dari hasil BNT 5\% rata-rata tinggi tanaman tertinggi pada perlakuan $\mathrm{d}_{2}$ (30 gram/10 liter) yaitu $30,17 \mathrm{~cm}$ pada umur $15 \mathrm{HST}$, $98,75 \mathrm{~cm}$ pada umur $30 \mathrm{HST}$ dan umur 45 HST 366,50 cm. Hal ini dimungkinkan karena pupuk gandasil D yaitu pupuk daun yang berfungsi sebagai penambah unsur hara pada tanaman. Gandasil D mengandung nitrogen $(\mathrm{N})$ $20 \%$, Nitrogen dibutuhkan dalam banyak pada pertumbuahn tanaman, karena nitrogen berperan dalam pembentukan klorofil serta sebagai penyusun protein dan protoplasma secara keseluruhan.

Mulyani dan Kartasapoetra (2002) mengemukakan bahwa pertumbuhan vegetatif sangat diperlukan unsur $\mathrm{N}$, karena unsur $\mathrm{N}$ sangat dibutuhkan untuk pembentukan klorofil, sintesis asam amino dan protein, asam nukleat

Dari hasil pengamatan pada fase generatif yaitu umur saat berbunga dan umur panen berpengaruh sangat nyata. Hasil BNT 5\% umur saat berbunga tercepat pada perlakuan $\mathrm{d}_{2}$ (30 gram/10 liter) yaitu 43,50 (44 hari) dan umur panen tercepat pada perlakuan $\mathrm{d}_{2}$ (30 gram/10 liter) yaitu 52,50 (53 hari). Hal ini disebabkan unsur hara Fosfat memberikan respon yang positif pada proses perkembangan bunga, buah dan biji.

Menurut Sutedjo (2010) saat keluar bunga pada tanaman sangat dipengaruhi oleh unsur fosfor yang mampu diserap 
oleh tanaman. didalam tanah fungsi $\mathrm{P}$ bagi tanaman adalah sebagai zat pembangun dan terikat dalam senyawasenyawa organik, sebagai zat pembangun $\mathrm{P}$ terpencar-pencar dalam tubuh tanaman, bagian tubuh tanaman yang berkaitan dengan pembiakan generatif, seperti pembentukan bunga dan buah, jadi dalam proses pembentukan bunga banyak membutuhkan P.

Pada hasil sidik ragam jumlah buah dan berat buah per tanaman tidak berpengaruh nyata, hal ini disebabkan pupuk Gandasil D tidak memberikan respon yang baik pada fase jumlah dan berat tanaman.

Hasil sidik ragam panjang buah per tanaman menunjukkan berpengaruh sangat nyata. Hasil BNT 5\% panjang buah per tanaman terpanjang terdapat pada perlakuan $\mathrm{d}_{1}(10 \mathrm{~g} / 10$ liter $)$ yaitu $81,15 \mathrm{~cm}$. Hal ini diduga unsur-unsur yang terkandung pada pupuk Gandasil D telah memberikan respon yang baik terhadap panjang buah tanaman kacang panjang. Menurut Nurahmi, dkk., (2011) menjelaskan bahwa fosfat mempunyai peranan penting dalam metabolisme tanaman, penghasil energi, dan juga berpengaruh positif terhadap pertumbuhan akar karena dengan meluasnya perakaran tanaman kemungkinan jumlah unsur hara yang diserap akan lebih banyak, sehingga mendorong pertumbuhan dan produksi tanaman menjadi lebih baik.

Pengaruh Interaksi Perlakuan Pupuk Kompos Solid Limbah Sawit dan upuk Daun Gandasil D Terhadap Pertumbuhan dan Hasil Tanaman Kacang Panjang (Vigna sinensis L.) varietas Parade Tavi. Berdasarkan hasil sidik ragam menunjukkan bahwa interaksi perlakuan (SxD) berpengaruh sangat nyata pada tinggi tanaman umur 15,30 , 45 HST, umur panen, jumlah buah per tanaman dan panjang buah per tanaman. Berpengaruh nyata pada umur saat berbunga. Berpengaruh tidak nyata pada berat buah per tanaman.

Perlakuan interaksi antara pupuk kompos dan gandasil D ratu Biogen berdasarkan analisis sidik ragam berpengaruh sangat nyata pada parameter tinggi tanaman umur $15,30,45$ HST, umur panen, jumlah buah per tanaman dan panjang buah per tanaman. Berpengaruh nyata pada parameter umur saat berbunga. Tinggi tanaman tertinggi pada interaksi $\mathrm{s}_{2} \mathrm{~d}_{2}$ yaitu $30,50 \mathrm{~cm}$ (umur 15 HST), 100,00 cm (umur 30 HST) dan $369,00 \mathrm{~cm}$ (umur $45 \mathrm{HST}$ ). Umur saat berbunga tercepat pada interaksi $\mathrm{s}_{1} \mathrm{~d}_{2}$ yaitu 43,00 (43 hari). Umur panen tercepat pada interaksi $\mathrm{s}_{1} \mathrm{~d}_{2}$ yaitu 52,00 (52 hari). Jumlah buah per tanaman terbanyak pada interaksi $\mathrm{s}_{1} \mathrm{~d}_{1}$ yaitu 8,69 (9 buah). Panjang buah per tanaman terpanjang pada interaksi $\mathrm{s}_{1} \mathrm{~d}_{1}$ yaitu 83,50 $\mathrm{cm}$. Hal ini disebabkan fungsi dari limbah solid kelapa sawit yang dapat memperbaiki sifat fisik tanah dan memberikan dampak positif terhadap pertumbuhan akar dan penyerapan unsur hara yang baik untuk pertumbuhan vegetatif tumbuhan. Selain itu Gandasil D sangat berperan pada pertumbuhan fase vegetatif, saat tanaman dalam masa pertumbuhan dan pemulihan setelah berbuah. Hasil penelitian menunjukkan bahwa perlakuan pupuk Gandasil B (B) berbeda nyata pada jumlah buah per 3 tanaman dan berbeda sangat nyata pada berat buah per 3 tanaman, dan berbeda tidak nyata pada panjang tanaman umur 2 minggu, 4 minggu dan 6 minggu setelah tanam, umur saat berbunga dan umur saat panen. Produksi polong tertinggi terdapat pada perlakuan $b_{3}$ (konsentrasi pupuk Gandasil B 6 g/l.air) dengan berat 322,92 g/3 tanaman, sedangkan produksi polong terendah terdapat pada perlakuan kontrol $\left(\mathrm{b}_{0}\right)$, yaitu $312,50 \mathrm{~g} / 3$ tanaman (Bulan dkk., 2016)

Hal ini sesuai dengan pendapat Munawar (2011) pemberian bahan 
organic dapat memperbaiki pori tanah sehingga menyediakan air dan udara bagi tanaman. Peningkatan laju fotosintesis akan meningkatkan fotosintat yang dihasilkan sebagai bahan pembentuk organ tanaman.

Bahan-bahan organik dapat digunakan untuk memperbaiki sifat fisik tanah seperti struktur dan porositas tanah. Pada dasarnya semua bahan-bahan organic padat dapat dikomposkan, misalnya limbah organik rumah tangga, kotoran/limbah

peternakan, limbah pertanian, limbah agroindustri, limbah pabrik kertas, limbah

pabrik gula, limbah pabrik kelapa sawit dan lain-lain (Crawford, 2003).

Menurut Riadi (2009) bahwa faktor yang mempengaruhi keberhasilan pemupukan melalui daun adalah konsentrasi larutan, jenis tanaman dan waktu pemberian. Ketersedian unsur hara yang cukup bagi tanaman yang disebabkan oleh berkurangnya kompetisi menyebabkan tanaman mampu memaksimalkan pembelahan sel meristem (sel muda) sehingga tanaman menjadi semakin tinggi seiring dengan bertambahnya umur tanaman.

\section{KESIMPULAN}

Berdasarkan hasil penelitian dan pembahasan dapat diambil kesimpulan yaitu, sebagai berikut : Pengaruh pemberian Pupuk Kompos Solid Limbah Sawit berbeda sangat nyata terhadap tinggi tanaman 15, 30 dan 45 HST, umur saat berbunga, umur panen dan panjang buah per tanaman. Panjang buah per tanaman terpanjang terdapat pada perlakuan $\mathrm{s}_{1}(40 \mathrm{~g} / \mathrm{tanaman})$ yaitu 81,15 $\mathrm{cm}$.

Pengaruh pemberian Pupuk Gandasil D berbeda sangat nyata terhadap tinggi tanaman 15,30 dan 45
HST, umur saat berbunga, umur panen dan panjang buah per tanaman. panjang buah per tanaman terpanjang terdapat pada perlakuan $d_{1}(10 \mathrm{~g} / 10$ liter air $)$ yaitu $81,15 \mathrm{~cm}$.

Pengaruh interaksi Pupuk Kompos Solid Limbah Sawit dan Pupuk Gandasil D berbeda sangat nyata terhadap tinggi tanaman umur 15, 30, 45 HST, umur panen, jumlah buah per tanaman dan panjang buah per tanaman. Berpengaruh nyata pada umur saat berbunga. Jumlah buah per tanaman terbanyak pada interaksi $\mathrm{s}_{1} \mathrm{~d}_{1}$ yaitu 8,69 (9 buah) dan panjang buah per tanaman terpanjang pada interaksi $\mathrm{s}_{1} \mathrm{~d}_{1}$ yaitu $83,50 \mathrm{~cm}$.

\section{DAFTAR PUSTAKA}

BPS Kaltim. (2015). Produksi Tanaman Sayur-sayuran. Diakses 20 Desember 2017, dari https://kaltim.bps.go.id/statictable/h tml.

Bulan, A., Napitupulu, M., \& Sutejo, H. (2016). Pengaruh Pupuk Gandasil B Dan Pupuk Kandang Ayam Terhadap Pertumbuhan Dan Hasil Tanaman Kacang Panjang (Vigna sinensis L.) The Effect of Gandasil B Fertilizer and Chicken Manure on The Growth and Yield of Long Bean (Vigna sinensis L). AGRIFOR, 15(1), 9-14.

Crawford, J. H. (2003). Composting of Agricultural Waste. In Biotechnology Applications and Research, Paul N, Cheremisinoff and R. P.Ouellette (ed).

Haitami, A., \& Wahyudi, W. (2019). Pengaruh berbagai dosis pupuk kompos tandan kosong kelapa sawit plus (kotakplus) dalam memperbaiki sifat kimia tanah 
ultisol. Jurnal Ilmiah Pertanian, 16(1), 56-63.

Hanafiah, K, A. (2005). Dasar-Dasar Ilmu Tanah. Jakarta: Rajagrafindo Persada.

Hardjowigeno. S. (2003). Ilmu Tanah. Jakarta: Akademi Presindo.

Kataren dan Djatmiko. (1981). Petunjuk Pemupukan Efektif. Jakarta: Agromedia Pustaka.

Mulyani, M dan A.G. Kartasapoetra. (2002). Pupuk dan cara pemupukan. Jakarta: Bina cipta.

Munawar, A. (2011). Kesuburan Tanah dan Nutrisi Tanaman. Bogor: ITB Press. .

Nurahmi, E.,Mahmud, dan Sylvia, R. (2011). Efektivitas Pupuk Organik terhadap Pertumbuhan Hasil Cabai
Merah. J. Floratek 158(6): 158164.

Okalia, D. Idris dan Rover. (2018). Efek Sisa Kompos Solid (kosplus) terhadap Pertumbuhan dan Produksi Tanaman Kacang Panjang (Vigna sinensis L.) pada Tanah Utisol. Primordia. 14(1):6-15.

Riadi, Sugeng. (2009). Pengaruh Jarak Tanam dan Pengaruh Pupuk Daun terhadap Pertumbuhan dan Produksi Kacang Hijau. Skripsi. Fakultas Pertanian. Unisda. Lamongan.

Sutedjo, M. M. (2010). Pupuk dan cara pemupukan. Jakarta: Rineka Cipta.

Yitnosumarto, S. (1993). Percobaan, Perancangan, Analisis dan Interpretasinya. Jakarta: Gramedia. 